\title{
Sequence of Pedal Peptide: A Novel Neuropeptide from the Central Nervous System of Aplysia
}

\author{
Philip E. Lloyd and Charles M. Connolly \\ Department of Pharmacological and Physiological Sciences and Committee on Neurobiology, The University of Chicago, \\ Chicago, Illinois 60637
}

\begin{abstract}
We report the identification of a novel neuropeptide from Aplysia nervous tissue. The peptide was termed Pedal peptide (Pep) because it was predominantly synthesized in the pedal ganglia. Pep was purified and sequenced from pooled extracts of pedal ganglia. The following sequence was proposed: Pro-Leu-Asp-Ser-Val-Tyr-Gly-Thr-His-Gly-Met-SerGly-Phe-Ala. Enzymatic hydrolysis procedures indicated that Pep had a free carboxyl terminal. A peptide with the proposed sequence was synthesized and compared with the native peptide. Chromatographic properties of the 2 peptides under 3 different conditions were compared and found to be identical. Electrophysiological responses to the 2 peptides were compared on an identified neuron in the abdominal ganglia and found to be qualitatively and quantitatively very similar. Both peptides produced net inward currents that were associated with a decrease in membrane conductance. The results from these 2 procedures confirmed that the proposed Pep sequence was correct. Quantitative measurements of the incorporation of ${ }^{35} \mathrm{~S}$-methionine into Pep suggest that cell bodies that synthesize Pep were present predominantly in the pedal ganglia but should also be found in other central ganglia as well. Pep-like immunoreactive neurons are found predominantly in the pedal ganglia and less frequently in the other ganglia (Pearson and Lloyd, 1989). Quantitatively, Pep constitutes one of the predominant peptides in the nervous system of Aplysia. Pep does not appear to be a member of any other previously identified invertebrate or vertebrate peptide family.
\end{abstract}

The sequences of a number of neuropeptides from Aplysia have been determined. These peptides were generally chosen for study because of their bioactivity or because they were located either in very large individual neurons or in homogeneous cell groups. Such peptides are amenable to sequencing either through molecular genetic approaches or through conventional protein-sequencing procedures (Kaldany et al., 1985; O'Shea and Schaffer, 1985; Scheller and Kirk, 1987). More general approaches to peptide identification may reveal physiologically important neuropeptides that do not fall into these categories and therefore resist identification. The approach that was pursued in the pres-

Received Apr. 7, 1988; revised May 19, 1988; accepted June 6, 1988.

We thank $W$. Pearson for critical reading of the manuscript. This work was supported by NIH Grant NS-23569 and a Whitehall grant.

Correspondence should be addressed to Philip E. Lloyd, Department of Pharmacological and Physiological Sciences and Committee on Neurobiology, The University of Chicago, 947 East 58th Street, Chicago, IL 60637.

Copyright (C) 1989 Society for Neuroscience $0270-6474 / 89 / 010312-06 \$ 02.00 / 0$ ent paper was to identify neuropeptides that were synthesized preferentially in a particular ganglia. This approach maximized the possibility that peptides identified in this mannor are transmitterlike and minimized the possibility that they were involved in general metabolic roles.

In the present report, we identify a novel neuropeptide from Aplysia nervous tissue. Pedal peptide (Pep) was purified and sequenced from pooled extracts of the pedal ganglia. The sequence was confirmed by comparing the chromatographic properties and biological activity of the native peptide and a synthetic peptide having the proposed sequence.

Quantitative measurements of the incorporation of radiolabeled methionine into Pep suggest that cell bodies that synthesize Pep should be present primarily in the pedal ganglia but should also be found in other central ganglia as well. This agrees with the distribution of neurons containing Pep-like immunoreactivity (Pearson and Lloyd, 1989). In terms of overall quantities of synthesis, Pep constitutes one of the predominant peptides in the nervous system of Aplysia. Homology searches suggest that the sequence of Pep is novel, and it does not appear to be a member of any other previously identified invertebrate or vertebrate peptide family.

\section{Materials and Methods}

Animals. Aplysia californica (100-300 gm) were obtained from Marinus, Inc., and maintained in circulating artificial seawater (ASW) tanks at $15^{\circ} \mathrm{C}$.

Extraction and purification of Pep. Animals were immobilized by an injection of isotonic $\mathrm{MgCl}_{2}$ equal to $25 \%$ of their body weight. The pedal/pleural ganglia complex was removed and pinned in dishes. The ASW covering the ganglia was replaced with a solution of $50 \%$ propylene glycol: $50 \%$ ASW at $0^{\circ} \mathrm{C}$, and the connective lissue sheath surrounding the ganglia was removed. The isolated ganglia were then placed in 0.5 $\mathrm{ml} 0.02 \mathrm{M}$ trifluoracetic acid (TFA, Pierce), heated to $100^{\circ} \mathrm{C}$ for $10 \mathrm{~min}$, homogenized, and centrifuged at $10,000 \times g$ for $10 \mathrm{~min}$. The supernatant was applied to a C18 cartridge (Sep-Pak, Waters Associates), and peptides were eluted with $3 \mathrm{ml} 75 \% \mathrm{CH}_{3} \mathrm{CN}, 25 \% \mathrm{H}_{2} \mathrm{O}, 0.01 \mathrm{M}$ TFA. The eluate was filtered (Acro LC13, Gelman Sciences), lyophilized, and dissolved in $0.5 \mathrm{ml} 0.01 \mathrm{M}$ TFA. It was then subjected to 2 steps of reverse-phase high-pressure liquid chromatography (RP-HPI C). All RPHPLC was carried out on a Brownlee C-8, RP 300, $4.6 \times 220 \mathrm{~mm}$ column. For the first purification, gradients from $5 \% \mathrm{CH}_{3} \mathrm{CN}, 95 \% \mathrm{H}_{2} \mathrm{O}$ to $70 \% \mathrm{CH}_{3} \mathrm{CN}, 30 \% \mathrm{H}_{2} \mathrm{O}$ in $40.5 \mathrm{~min}$ were used. In the first step, 0.01 M TFA was the counterion, while in the second step, $0.01 \mathrm{M}$ heptafluorobutyric acid (HFBA, Pierce) was used. Flow rates were $1 \mathrm{ml} / \mathrm{min}$. All subsequent purifications used RP-HPLC with the same 2 counterions but in reversed order and with slightly different gradients at a flow rate of $2 \mathrm{ml} / \mathrm{min}$.

Amino acid analysis and sequence determination. Purified Pep was hydrolyzed under vacuum at $110^{\circ} \mathrm{C}$ in $6 \mathrm{~N} \mathrm{HCl}, 0.1 \%$ phenol for $24 \mathrm{hr}$. The resulting amino acids were derivatized with phenylisothiocyanate and analzyed using Picotag columns, reagents, and methodology (Waters Associates). Norleucine was added prior to hydrolysis as a standard. 
Purified Pep was subjected to automated Edman degradation on an Applied Biosystems (Foster City, CA) 470A gas-phase sequencer. Samples were loaded onto a glass-fiber filter treated with $3 \mathrm{mg}$ Polybrene and $0.2 \mathrm{mg} \mathrm{NaCl}$. The filter was precycled 3 times before sequence analysis. Phenylthiohydantoin (PTH) amino acid derivatives were analyzed on a Hewlett-Packard model 1090 HPLC equipped with an IBM cyano column.

Determination of the carboxyl terminal. Pedal ganglia were labeled in cold sterilized $(0.2 \mu \mathrm{m}$ filter) $25 \%$ Aplysia blood, $75 \%$ ASW containing antibiotics (penicillin, 25 units $/ \mathrm{ml}$; streptomycin, $25 \mu \mathrm{g} / \mathrm{ml}$ ), $0.01 \%$ 2-mercaptoethanol, and $0.3 \mathrm{mCi}^{3} \mathrm{H}$-alanine/ $\mathrm{ml}$ for $15 \mathrm{hr}$ followed by a $4 \mathrm{hr}$ chase period. The ganglia were then desheathed, extracted, Pep purified as described above, and treated with 5 units of immobilized (agarose bound) chymotrypsin (Worthington) in $200 \mu \mathrm{l} 20 \mathrm{~mm}$ Tris (pH 7.7), $10 \mathrm{mM} \mathrm{CaCl}_{2}$. After $5 \mathrm{~min}, 100 \mu \mathrm{l}$ was removed, and filtered $(0.45$ $\mu \mathrm{m})$. After $100 \mathrm{~min}$, the remaining $100 \mu \mathrm{l}$ was removed and filtered. Then, $2 \mu \mathrm{mol}$ alanine and alanine-amide (Sigma) were added to each sample. The mixture was lyophilized and run on ion-exchange HPLC using a Brownlee CX-300, $4.6 \times 100 \mathrm{~mm}$ column run isocratically at $20 \mathrm{~mm}$ triethylamine acetate (TEAAc), $\mathrm{pH} 5.5$, with a flow rate of 1 $\mathrm{ml} / \mathrm{min}$. Samples were collected and counted.

Native Pep was purified as described above, and $2 \mathrm{nmol}$ (estimated from absorbance at $215 \mathrm{~nm}$ ) was treated with carboxypeptidase $\mathrm{A}$ (Boehringer Mannheim) in $0.02 \mathrm{M}$ phosphate buffer, $\mathrm{pH} 8.1$, for $2 \mathrm{hr}$ at $22^{\circ} \mathrm{C}$. The enzyme/peptide/buffer ratio was $2.5 \mu \mathrm{g} / \mathrm{nmol} / 10 \mu \mathrm{l}$ buffer. The reaction was stopped by addition of 4 vol ice-cold incubation buffer. Identical amounts of the peptides were treated exactly as experimentals except for the addition of protease. Hydrolysis was determined by change in retention time on RP-HPIC with TF.AAc as counterion. Two amidated synthetic peptides (FMRFamide and $\mathrm{SCP}_{\mathrm{B}}$ ) were also tested and were not hydrolyzed by this batch of carboxypeptidase A.

Chromatographic comparisons of the native and synthetic peptides. Commercially synthesized peptide was obtained (Applied Biosystems, Foster City, CA). The retention times of the synthetic and native peptides were compared in 3 different modes of HPLC. In the first mode, gradients from $14 \% \mathrm{CH}_{3} \mathrm{CN}, 86 \% \mathrm{H}_{2} \mathrm{O}$ to $17.5 \% \mathrm{CH}_{3} \mathrm{CN}, 82.5 \% \mathrm{H}_{2} \mathrm{O}$ in $2.05 \mathrm{~min}$, then to $21.7 \% \mathrm{CH}_{3} \mathrm{CN}, 78.3 \% \mathrm{H}_{2} \mathrm{O}$ in $12.3 \mathrm{~min}$, then to $28 \% \mathrm{CH}_{3} \mathrm{CN}, 72 \% \mathrm{H}_{2} \mathrm{O}$ in $4.1 \mathrm{~min}$ were used. $\mathrm{THA}, 0.01 \mathrm{M}$, was the counterion. In the second mode, gradients from $7 \% \mathrm{CH}_{3} \mathrm{CN}, 93 \% \mathrm{H}_{2} \mathrm{O}$ to $31.5 \% \mathrm{CH}_{3} \mathrm{CN}, 68.5 \% \mathrm{H}_{2} \mathrm{O}$ in $18 \mathrm{~min}$ were used. TEAAc, $20 \mathrm{~mm}$, was the counterion. In the third mode, HPLC was operated isocratically at $29 \% \mathrm{CH}_{3} \mathrm{CN}, 71 \% \mathrm{H}_{2} \mathrm{O}$ with $0.01 \mathrm{M} \mathrm{HFBA}$ as the counterion.

Electrophysiological comparisons of the native and synthetic peptides. Abdominal ganglia were desheathed manually. Neuron L5 was identified visually (Frazier et al., 1967) and penetrated with 2 single-barrel electrodes $(5 \mathrm{M} \Omega)$; one was used to pass current and the other to monitor voltage. The bath was superfused at a flow rate of 1 bath volume $(2.5$ $\mathrm{ml} / \mathrm{min}$. Typically, recordings were carried out in a modified ASW containing $2 \mathrm{~mm} \mathrm{CaCl}_{2}(0.2 \times$ normal $)$ and $110 \mathrm{~mm} \mathrm{MgCl}_{2}(2 \times$ normal $)$ to reduce chemical synaptic transmission. Native Pep (quantities estimated by absorbance at $215 \mathrm{~nm}$ ) or synthetic Pep were introduced into the bath via a pipette in $50 \mu \mathrm{l}$ modified ASW. Recordings were carried out either with no injected current or with manual voltage clamp in which current was injected to keep the holding membrane potential steady, and conductance changes were measured with constant-current pulses.

\section{Results}

Identification of a peptide by its selective synthesis in the pedal ganglia

A survey was carried out directed towards measuring the incorporation of labeled methionine into peptides in each of the 5 ganglia that comprise the CNS of Aplysia. All the ganglia, including the closely apposed pleural and pedal ganglia, were surgically separated before incubation in media containing ${ }^{35} \mathrm{~S}-$ methionine. This precaution insured that any labeled peptides found in ganglia extracts must have been synthesized by cell bodies in those ganglia. In addition, colchicine was added to the media to prevent transport of labeled peptides from cell bodies into nerves or the sheath. After a period of time to allow for incorporation and processing events, the ganglia were manually desheathed and the cell body and neuropil regions extract-

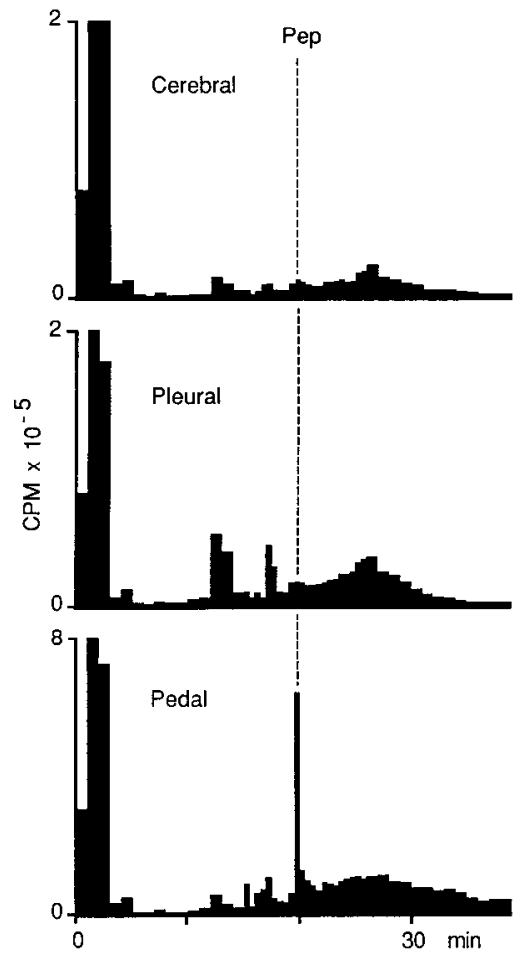

Figure 1. Incorporation of ${ }^{3} \mathrm{~S}$-methionine into peptides in cerebral, pleural, and pedal ganglia from 1 animal. Ganglia were incubated in the presence of colchicine to inhibit axonal transport. Connective tissue was removed from ganglia before extraction. Note different scale for the pedal ganglia, which were approximately 4 -fold larger than cerebral or pleural ganglia. Radiolabel with short retention time (1-2 min) was primarily unincorporated methionine and was off-scale. RP-HPLC with TFA as a counterion.

ed. These extracts were run on RP-HPLC and the resulting samples counted. Figure 1 shows an example of the profile of incorporation of methionine for the 3 ganglia that make up the circumesophageal ring of Aplysia. Note that the major peak of label (termed Pep) was predominantly present in the extracts from the pedal ganglia.

\section{Purification and sequencing of Pep}

Extracts of pooled desheathed pedal ganglia were used as the starting material for the purifications. This extract was passed through a reverse-phase cartridge and then run on RP-HPLC with TFA as a counterion. Figure 2 shows an example of a purification using an extract pooled from 18 pedal ganglia. The absorbance peak with the same retention time as the radiolabeled peak described in Figure 1 was dried and run on the same RP-HPLC column but with HFBA as the counterion (Fig. 2). At this stage, the peptide appeared to be pure as judged from the shape of the absorbance peak.

A quantitative amino acid analysis of Pep yielded the values presented in Table 1. Based on this composition and a formula that predicts the retention times of peptides on RP-HPLC (Guo et al., 1985), these values were interpreted as representing a 15 amino acid residue peptide. The material used for the amino acid analysis was purified from the pedal ganglia from 12 animals. This suggests that Pep is present at levels of about $1 \mathrm{nmol}$ per pedal ganglia pair.

Sequence analysis of another sample of Pep produced the sequential yields shown in Figure 3. The yield dropped markedly 

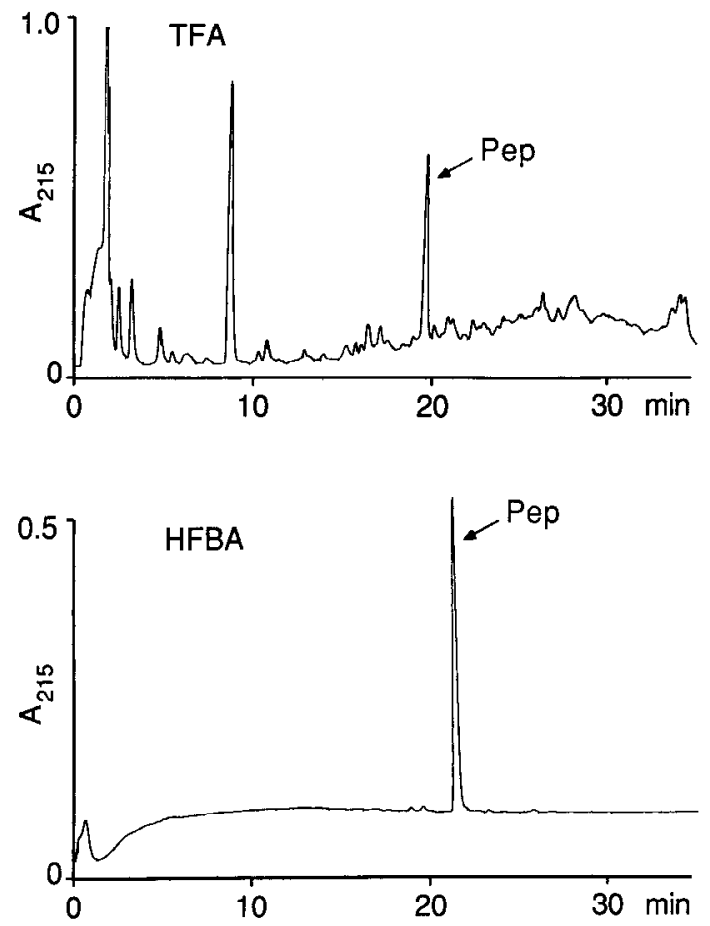

Figure 2. Absorbance profiles of the 2 analytical RP-HPLC procedures used to purify Pep from pooled extracts of 18 desheathed pedal ganglia. Top trace, TFA used as the counterion. The peak termed Pep was dried and run with HFBA as the counterion. This step separates Pep from a few minor contaminants and the peak shape suggests that the peptide has been purified to homogeneity.

after cycle 15 , indicating that the complete primary sequence of a 15 amino acid peptide had been obtained. However, the sequencing method used does not distinguish between amidated and free carboxyl terminals. As roughly half of the known bioactive peptides are amidated (Eipper et al., 1986), it was important to determine if this was the case for Pep. Two enzymatic methods were used to determine if the carboxyl terminal alanine residue was amidated. The first procedure involved enzymatically cleaving the carboxyl terminal alanine from the peptide and determining if it was amidated. In this procedure, Pep was purified from pedal ganglia incubated with ${ }^{3} \mathrm{H}$-alanine. The labeled Pep was incubated with chymotrypsin, which would yield a single labeled fragment of alanine with a free carboxyl terminal or alanine-amide. These 2 could be separated from each other by cation-exchange HPLC. When the labeled Pep was incubated with chymotrypsin, no alanine-amide was produced. In the second procedure, unlabeled Pep was incubated with carboxypeptidase A (CPA), an exopeptidase that cleaves amino acids from the carboxyl terminal of nonamidated peptides but is unable to cleave if the terminal is amidated (Chang and Lccman, 1971). CPA effectively hydrolyzed Pep, again indicating that its carboxyl terminal is a free acid. Two amidated peptides were tested in parallel and were not hydrolyzed. Taken together, these data indicate that the sequence of Pep was the 15 residue peptide with a free carboxyl terminal shown in Figure 3. A synthetic peptide with this sequence was obtained from a commercial source, and the properties of the native and synthetic peptides were compared.
Table 1. Amino acid composition of Pep

\begin{tabular}{lll} 
Amino acid & $\begin{array}{l}\text { Quantity } \\
\text { (nmol) }\end{array}$ & Ratio \\
\hline Gly & 30.7 & 3 \\
Ser & 14.8 & 2 \\
Ala & 10.1 & 1 \\
Asp & 10.8 & 1 \\
His & 10.0 & 1 \\
Leu & 10.0 & 1 \\
Met & 7.5 & 1 \\
Phe & 10.9 & 1 \\
Pro & 10.0 & 1 \\
Thr & 10.2 & 1 \\
Tyr & 7.6 & 1 \\
Val & 10.7 & 1 \\
Arg & 0.2 & 0 \\
Glu & 0.5 & 0 \\
Ile & 0.2 & 0 \\
Lys & 0.2 & 0
\end{tabular}

Pedal ganglia from 12 animals were used as starting material for the purification of Pep used in this analysis.

\section{Comparison of the properties of native and synthetic peptides}

Synthetic and native Pep were analyzed by 3 RP-HPLC procedures using HFBA ( $\mathrm{pH} 2.0$ ), TFA (pH 2.0), or TEAAc ( $\mathrm{pH}$ 5.5) as counterions (Fig. 4). In each procedure, each peptide was first injected alone and then a mixture of the 2 peptides was injected and the uv absorbance monitored at a fast recording speed. When injected independently, the 2 peptides had very similar chromatographic properties. When injected as a mixture, the 2 peptides produced a single absorbance peak with smooth rising and falling phases in each of the 3 different chromatographic procedures. These results strongly suggest that native and synthetic Pep are chemically identical.

The biological activities of the synthetic and native peptides were also compared. Dense networks of fibers and varicosities with Pep-like immunoreactivity were observed on a number of neuronal cell bodies in Aplysia (Pearson and Lloyd, 1989). These networks were particularly pronounced on the cell bodies of identified neurons L2, L3, and L5 (Frazier et al., 1967). Application of Pep to these neurons produced a depolarization that was apparently produced by a decrease in membrane conductance. The threshold for this action was approximately $10^{-8} \mathrm{M}$. Although a thorough survey was not carried out, several other large identified neurons (e.g., R2 and R15) that did not have Pep-like immunoreactive terminals on their cell bodies were much less responsive to Pep. The biological actions of native and synthetic Pep were compared on L5 (Fig. 5). This neuron was chosen because it can be reliably identified by visual criteria alone and because it normally shows little spontaneous electrical activity (Frazicr et al., 1967). Thesc experiments werc carricd out in a modified ASW $\left(0.2 \times\left[\mathrm{Ca}^{2+}\right] ; 2 \times\left[\mathrm{Mg}^{2+}\right]\right)$, which markedly depresses chemical synaptic transmission and reduces the possibility that the effects of Pep are produced by activation of neurons presynaptic to L5. In current clamp, both native and synthetic Pep produced similar long-lasting depolarizations and bursting activity in L5. Using the manual voltage-clamp procedure, both native and synthetic Pep produced a net inward current of similar amplitude that was associated with an increase 


$\begin{array}{ccccccccccccccc}1 & 2 & 3 & 4 & 5 & 6 & 7 & 8 & 9 & 10 & 11 & 12 & 13 & 14 & 15 \\ \text { Pro Leu } & \text { Asp } & \text { Ser } & \text { Val } & \text { Tyr } & \text { Gly } & \text { Thr } & \text { His } & \text { Gly } & \text { Met } & \text { Ser } & \text { Gly } & \text { Phe } & \text { Ala } \\ 5.58 & 6.04 & 2.97 & 0.35 & 3.45 & 2.98 & 2.41 & 0.23 & 0.53 & 2.13 & 2.43 & 0.13 & 1.11 & 1.08 & 0.46\end{array}$

Figure 3. Proposed primary sequence for Pep. Top row, cycle number; middle row, dominant amino acid in each cycle of the sequencing run; bottom row, yields from each cycle in nmol. Yields for amino acids with hydroxyl side groups (i.e., serine and threonine) were markedly lower than other amino acids in this sequencing procedure. The yields dropped off sharply after cycle 15 .

in the amplitude of the voltage deflections produced by brief constant-current pulses. This suggests that this inward current was produced by a decrease in total membrane conductance. In these experiments, injections of $1 \mathrm{nmol}$ Pep into the bath would briefly produce a maximal concentration of about $4 \times 10^{-7} \mathbf{M}$. The responses shown in Figure 5 were by no means maximal. Application of 10 and $100 \mathrm{nmol}$ synthetic Pep to the same L5 produced net inward currents of 8.8 and $18.8 \mathrm{nA}$, respectively. Thus, the electrophysiological effects of native and synthetic Pep on L5 were qualitatively and quantitatively identical.

These experiments demonstrate that the synthetic Pep, which was synthesized to match our proposed sequence, and native Pep have the samc chromatographic and biological activity. Thus, the proposed sequence for Pep was confirmed.

\section{Pep is synthesized in the other central ganglia}

Pep-like immunoreactive neuronal cell bodies were also observed in ganglia other than the pedal, although these neurons were smaller and considerably less abundant (Pearson and Lloyd, 1989). If these cell bodies actually synthesize Pep, it should be possible to measure the synthesis of Pep in other ganglia. Isolated ganglia were labeled with ${ }^{35} \mathrm{~S}$-methionine in the presence of colchicine to block axonal transport of peptides. The ganglia were manually desheathed and the cell body and neuropil re-

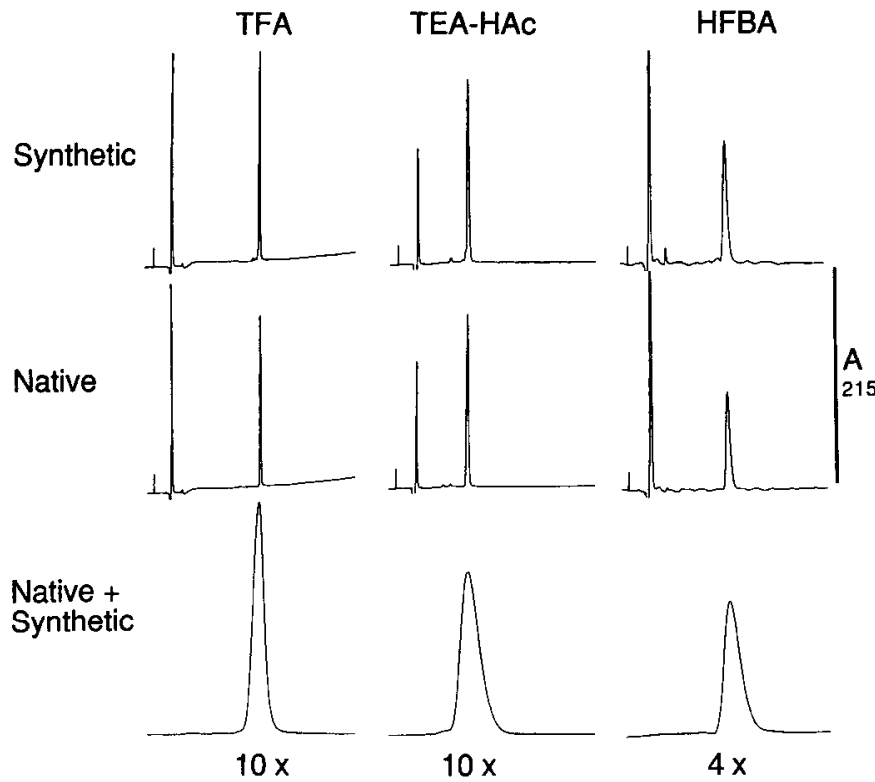

Figure 4. Comparison of the chromatographic properties of a synthetic peptide with the proposed Pep sequence and native Pep purified from extracts of pedal ganglia. RP-HPLC was carried out using 3 different counterions: TFA (pH 2.0); triethylamine acetate (TEA-HAc, $\mathrm{pH} 5.5$ ); and HFBA (pH 2.0). For each counterion, the bottom trace shows the absorbance peak of a sample comprised of half synthetic and half native Pep at an increased chart speed ( 10 or $4 \times$ normal). gions extracted. Extracts from ganglia from 3 animals were pooled to reduce animal-to-animal variability. Known quantities of unlabeled synthetic Pep were added to the extracts before they were analyzed by a sequential 3-step procedure employing RPHPLC with 3 counterions: HFBA, TFA, and TEAAc (Fig. 6). This 3-step purification was used because it separated Pep from other labeled peptides even when it was synthesized in small quantities. The recovery of the labeled Pep was determined from the recovery of the cold Pep and was very similar for each ganglia extract. Taking total Pep synthesis in the CNS as $100 \%$, the

\section{A}
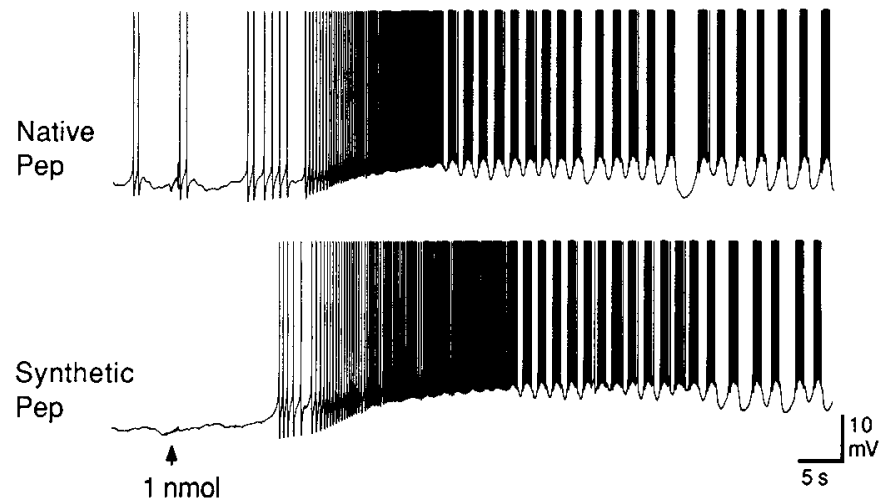

B
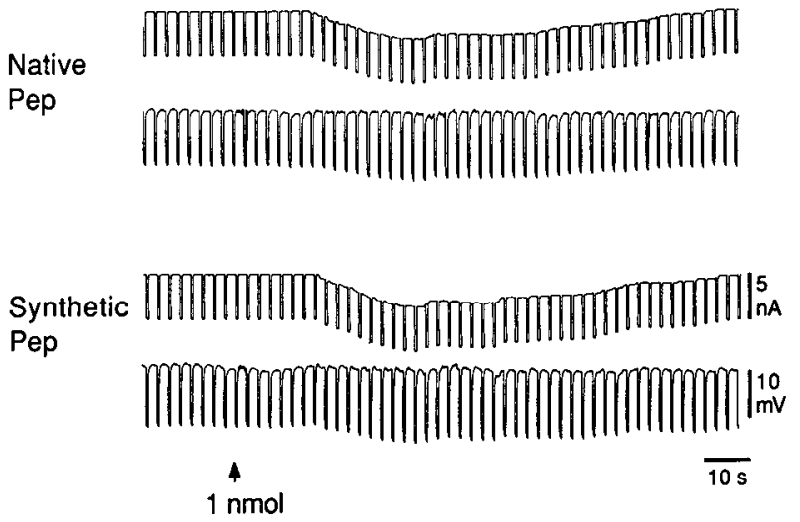

Figure 5. Comparison of the biological properties of a synthetic peptide with the proposed Pep sequence and native Pep purified from extracts of pedal ganglia. Current clamp $(A)$ and manual voltage clamp $(B)$ records from neuron L5 in a desheathed abdominal ganglia. In each record, $1 \mathrm{nmol}$ of either native or synthetic Pep was delivered into the bath by pipette. In the current-clamp mode, no current was injected into the cell. In the manual voltage clamp, constant-current pulses and steady current injection to hold the neuron at rest potential $(-45 \mathrm{mV})$ were applied through one electrode and a second electrode was used to monitor membrane potential. Similar results were obtained in 2 additional experiments. 


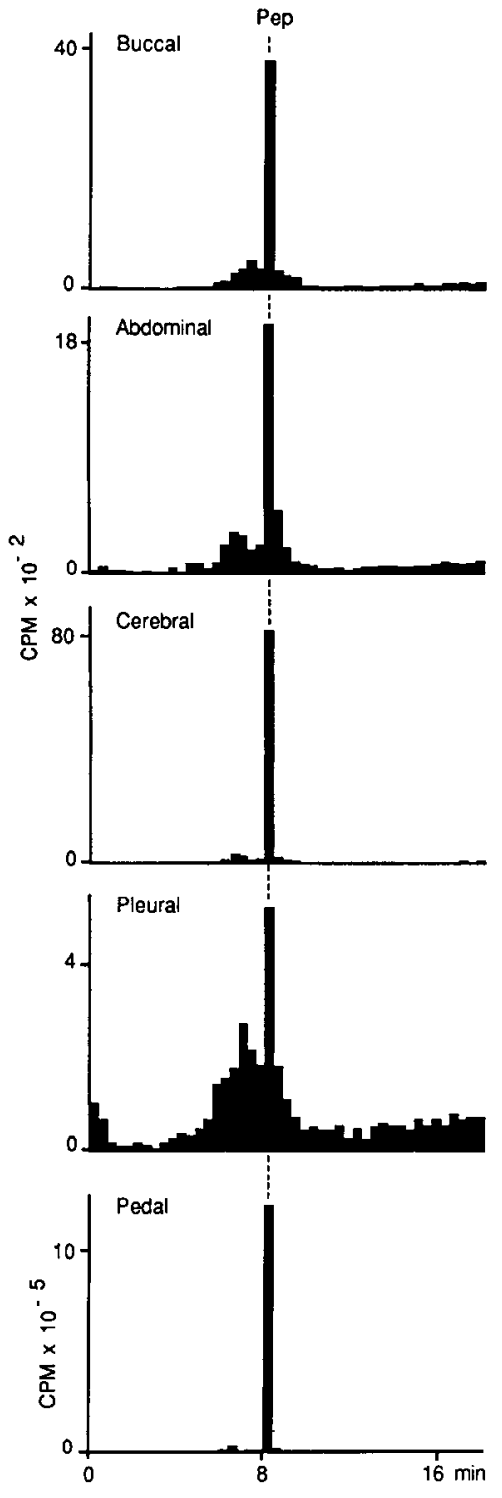

Figure 6. Final HPLC run (counterion: TEA-HAc) of a sequential 3-step purification of ${ }^{35} \mathrm{~S}$-methionine labeled Pep from ganglia. Conditions were optimized so that nearly all Pep (note pedal ganglia profile) was collected into a single sample (dashed line). These data were from extracts pooled from 3 animals.

percentages of total Pep synthesis per ganglia was as follows: pleural, $0.04 \%$; abdominal, $0.16 \%$; buccal, $0.30 \%$; cerebral, $0.66 \%$; and pedal, $98.8 \%$. Thus, the other ganglia do synthesize Pep but at rates less than $1 \%$ of that of the pedal ganglia.

\section{Discussion}

In the present study, we have outlined the identification, purification, and sequencing of a novel neuropeptide termed Pep because it was synthesized predominantly in the pedal ganglia. We have also described the confirmation of the proposed sequence by a comparison of the chromatographic and biological properties of native and synthetic Pep. Although Pep is synthesized predominantly in the pedal ganglia, it is also synthesized in each of the other central ganglia in Aplysia. However, Pep is not synthesized at particularly low rates in the other ganglia. For example, if one assumes that relative rates of synthesis are similar to relative concentrations in the ganglia, then the amounts of Pep in the abdominal, buccal, and cerebral ganglia were in the range of 2-8 pmol. These values are not markedly different from the range of 5-20 pmol per ganglia for FMRFamide in the abdominal, cerebral, and buccal ganglia or for $\mathrm{SCP}_{\mathrm{B}}$ in the pleural, abdominal, and cerebral ganglia (Lehman ct al., 1984; Lloyd ct al., 1985). Prcsumably, the high rates of Pep synthesis in the pedal ganglia are required to support the extremely high rates of transport of the peptide down peripheral nerves (Pearson and Lloyd, 1989). The results on the rates of Pep synthesis in the ganglia are consistent with an immunocytological study in which Pep-like immunoreactive neurons were large and abundant in the pedal ganglia, smaller and less abundant in the cerebral, buccal, and abdominal ganglia, and very small and sparse in the pleural ganglia (Pearson and Lloyd, 1989).

The bioassay used to confirm that synthetic and native Pep had identical biological activity was a comparison of the electrophysiological effects of the peptides. Neuron L5 in the abdominal ganglia was chosen for this study because its cell body was covered with a network of fibers and varicosities containing Pep-like immunoreactivity. Thus, it is very likely that L5 is a postsynaptic target for an, as yet, unidentified Pep-containing neuron and has receptors to Pep on the surface of its cell body. Indeed, L5 and several other large neurons with immunoreactive networks on their cell bodies were much more sensitive to Pep application than several other large neurons lacking such networks. We are presently investigating the nature of the ionic currents involved in this decreased conductance depolarization.

Pep is presumably cleaved from a precusor protein, as is the case for other neuropeptides (Eipper et al., 1986). It will be interesting to determine if other biologically active peptides are also present in the same precursor. However, our analyses of labeled peptides in the pedal ganglia suggest that no other methionine-containing peptides are synthesized in quantities comparable to Pep. It is still possible that other peptides in the precursor do not contain methionine residues or are present with fewer copies per precursor. Now that the major population of Pep-synthesizing neurons have been identified in the pedal ganglia (Pearson and Lloyd, 1989), it will be possible to test this possibility using labeled amino acids other than methionine or by molecular genetic determination of the precursor sequence. Pep appears to be the first identified member of a new peptide family. Neither homology searches or manual perusal of neuropeptide sequences has revealed any significant sequence similarities with known peptides.

There are a number of reasons to believe that Pep will play an important role in the physiolngy of Aplysia. Foremost among these is that Pep is present in such high concentrations in the pedal ganglia. Another reason is that Pep has widespread distribution within the CNS and periphery (Pearson and Lloyd, 1989). Finally, in addition to as yet undetermined peripheral actions of the peptide, we have provided evidence that Pep has potent and selective actions on the electrophysiological properties of central neurons.

\section{References}

Chang, M. M., and S. E. Leeman (1971) Amino acid sequence of Substance P. Nature [New Biol.] 232: 86-87.

Eipper, B. A., R. E. Mains, and E. Herbert (1986) Peptides in the nervous system. Trends Neurosci. 9: 463-468.

Frazier, W. T., E. R. Kandel, I. Kupfermann, R. Waziri, and R. E. Coggeshall (1967) Morphological and functional properties of iden- 
tified neurons in the abdominal ganglion of Aplysia californica. $\mathrm{J}$. Neurophysiol. 30: 1288-1351.

Guo, D., C. T. Mant, J. M. R. Parker, and R. S. Hodges (1985) Hydrophobicity parameters in peptides. 1. Prediction of peptide retention in reversed-pase HPLC (RPC). 2. Prediction of hydrophobic regions on the surface of proteins. Proc. Am. Peptide Symp. 9: 2327.

Kaldany, R.-R. J., J. R. Nambu, and R. H. Scheller (1985) Neuropeptides in identified Aplysia neurons. Annu. Rev. Neurosci. 8: 431456.

Lehman, H. K., D. A. Price, and M. J. Greenberg (1984) The FMR Famide-like peptide of Aplysia is FMRFamide. Biol. Bull. 167: $460-466$.
Lloyd, P. E., A. C. Mahon, 1. Kupfermann, J. L. Cohen, R. H. Scheller, and K. R. Weiss (1985) Biochemical and immunocytological localization of small cardioactive peptides in the nervous system of Aplysia californica. J. Neurosci. 5: 1851-1861.

O'Shea, M., and M. Schaffer (1985) Neuropeptide function: The invertebrate contribution. Annu. Rev. Neurosci. 8: 171-198.

Pearson, W. L., and P. E. Lloyd (1989) Immunocytological localization of pedal peptide in the central nervous system and periphery of $A p l y$ sia. J. Neurosci. 9: 318-325.

Scheller, R. H., and M. D. Kirk (1987) Neuropeptides in identified Aplysia neurons: Precursor structure, biosynthesis and physiological actions. Trends Neurosci. 10: 46-52. 